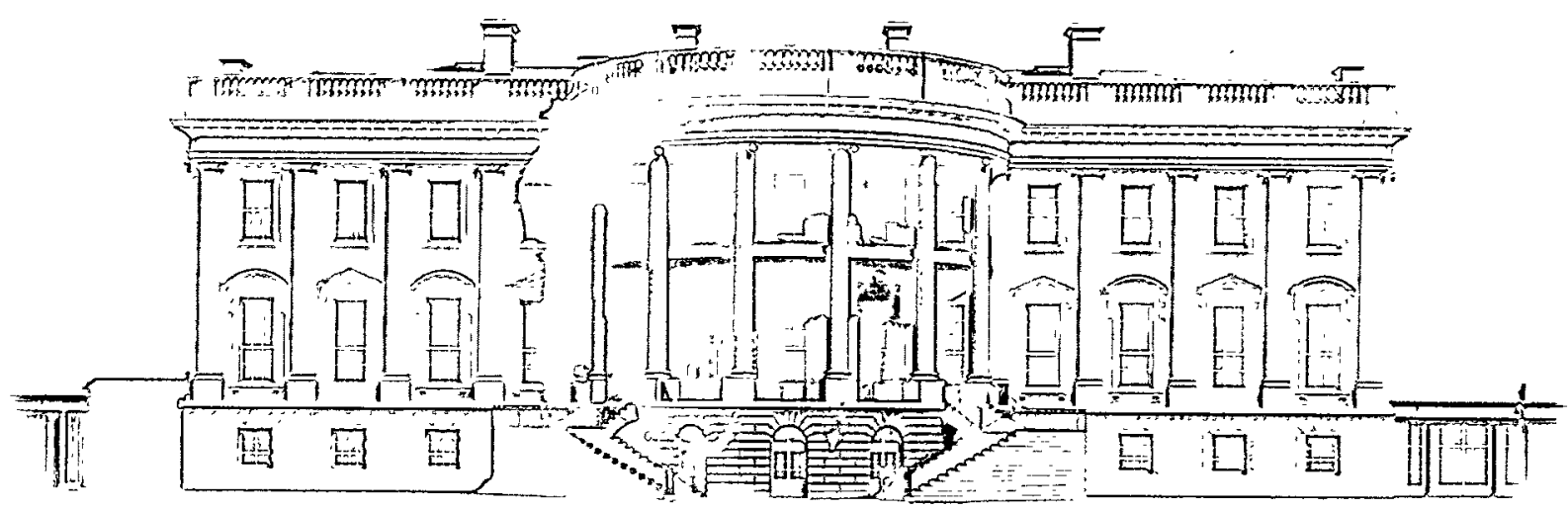

GREENING OF THE WHITE HOUSE
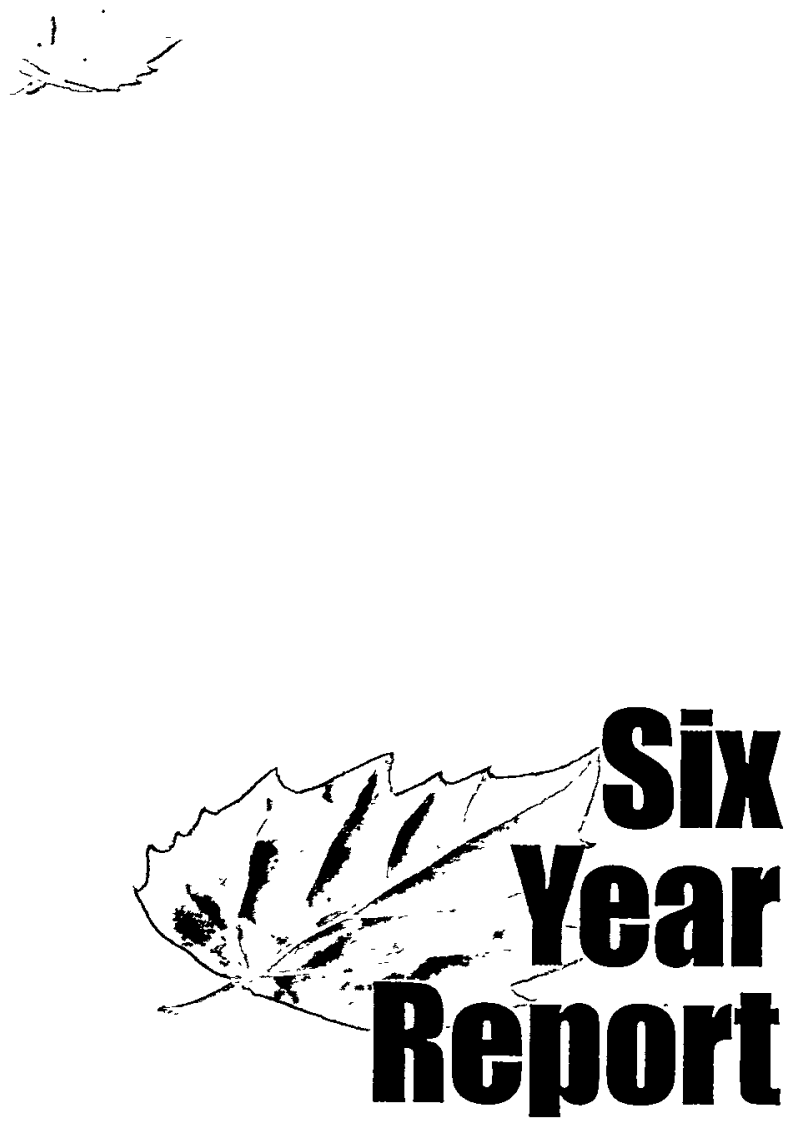

November 1999 


\section{How to Order}

To order a free copy of this report, call the Energy Efficiency and Renewable Energy Clearinghouse at 1-800-373-3732 or visit the Federal Energy Management Program home page at www.eren.doe.gov/femp and go to "Order Materials." 


\section{DISCLAIMER}

This report was prepared as an account of work sponsored by an agency of the United States Government. Neither the United States Government nor any agency thereof, nor any of their employees, make any warranty, express or implied, or assumes any legal liability or responsibility for the accuracy, completeness, or usefulness of any information, apparatus, product, or process disclosed, or represents that its use would not infringe privately owned rights. Reference herein to any specific commercial product, process, or service by trade name, trademark, manufacturer, or otherwise does not necessarily constitute or imply its endorsement, recommendation, or favoring by the United States Government or any agency thereof. The views and opinions of authors expressed herein do not necessarily state or reflect those of the United States Government or any agency thereof. 


\section{DISCLAIMER}

Portions of this document may be illegible in electronic image products. Images are produced from the best available original document. 


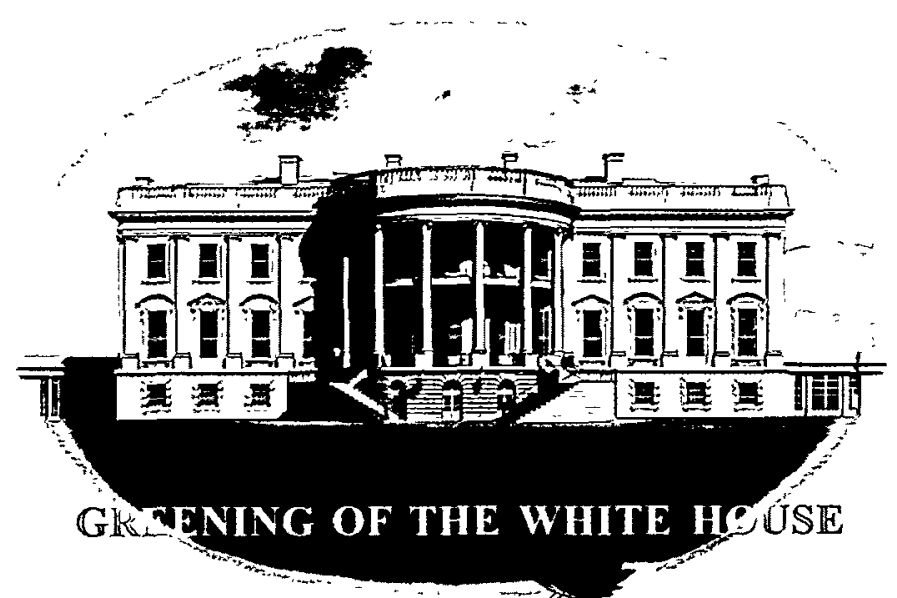

We're going to identify what it takes to make the White House a model for efficiency and waste reduction, and then we're going to get the job done. I want to make the White House a model for other Federal agencies, for State and local governments, for business, and for families in their homes. Before I ask you to do the best you can in your house, l ought to make sure $I$ ' $m$ doing the best $l$ can in my house.

President Clinton

April 21, 1993 


\section{Acknowledgments}

This report is the result of a one-year effort that brought together more than two dozen people from both within and outside the Federal Government. The report builds on a process begun in 1993 designed to tap the best thinking on energy conservation and waste reduction and apply that knowledge to the White House complex.

The authors wish to recognize the critical support provided by George Frampton, Chair of the Council on Environmental Quality; Roger Ballentine, Deputy Assistant to the President for Environmental Initiatives; and Beth Shearer in her positions at both the General Services Administration and the Department of Energy. Mention must also be made of the contributions of Mark Lindsay, Assistant to the President for Management and Administration; Mike Lyle, Director, Office of Administration (Executive Office of the President) and Donald Plummer, Buildings Manager, General Services Administration.

Special thanks go to John Archibald, Anne Sprunt Crawley, Dean McCauley, and Katie McGervey of the Federal Energy Management Program at the Department of Energy, all of whom provided insight and guidance throughout the Greening Initiative. Andy Walker of the Department of Energy's National Renewable Energy Laboratory (NREL) and NREL intern Lori Mitchell helped coordinate the energy audit of Jackson Place. Also involved with the Jackson Place audit was the Environmental Protection Agency's (EPA) Indoor Air Quality Team, lead by Bob Thompson and including Bryan Ligman, Gene Fisher, Garvin Heath, Greg Brunner, Susan Womble, and Ralph Wright.

Dana Arnold of the Office of the Federal Environmental Executive provided support on waste reduction and recycling issues.

Shelley Fidler of the White House Climate Change Task Force and David Rejeski, EPA agency representative to the Council on Environmental Quality, provided overall project management.

Bill Browning of the Rocky Mountain Institute helped pull together the environmental history of the White House complex. Paul Jutton of the Office of Administration (Executive Office of the President) provided graphics for the report, and Chris Tremper of McNeil Technologies, Inc., oversaw the report's final production. 


\section{Table of Contents}

An Introduction .......................................................................... Page 1

What are the White House "Greening Measures"? ...................................... Page 2

Take the Greening of the White House Tour .............................................. Page 3

The White House ..................................................................... Page 4

White House Greening Activities ........................................... Page 6

The Old Executive Office Building ............................................ Page 11

Old Executive Office Building Greening Activities ........................... Page 12

Jackson Place ................................................................. Page 17

Jackson Place Greening Activities ............................................. Page 18

The Bottom Line-Energy Efficiency Measures in Place ................................ Page 20

Environmental Bottom Line ............................................................. Page 22

The Greening Process ...................................................................... Page 24

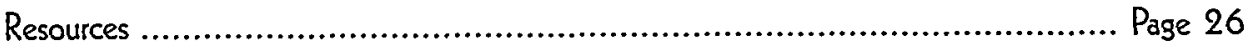



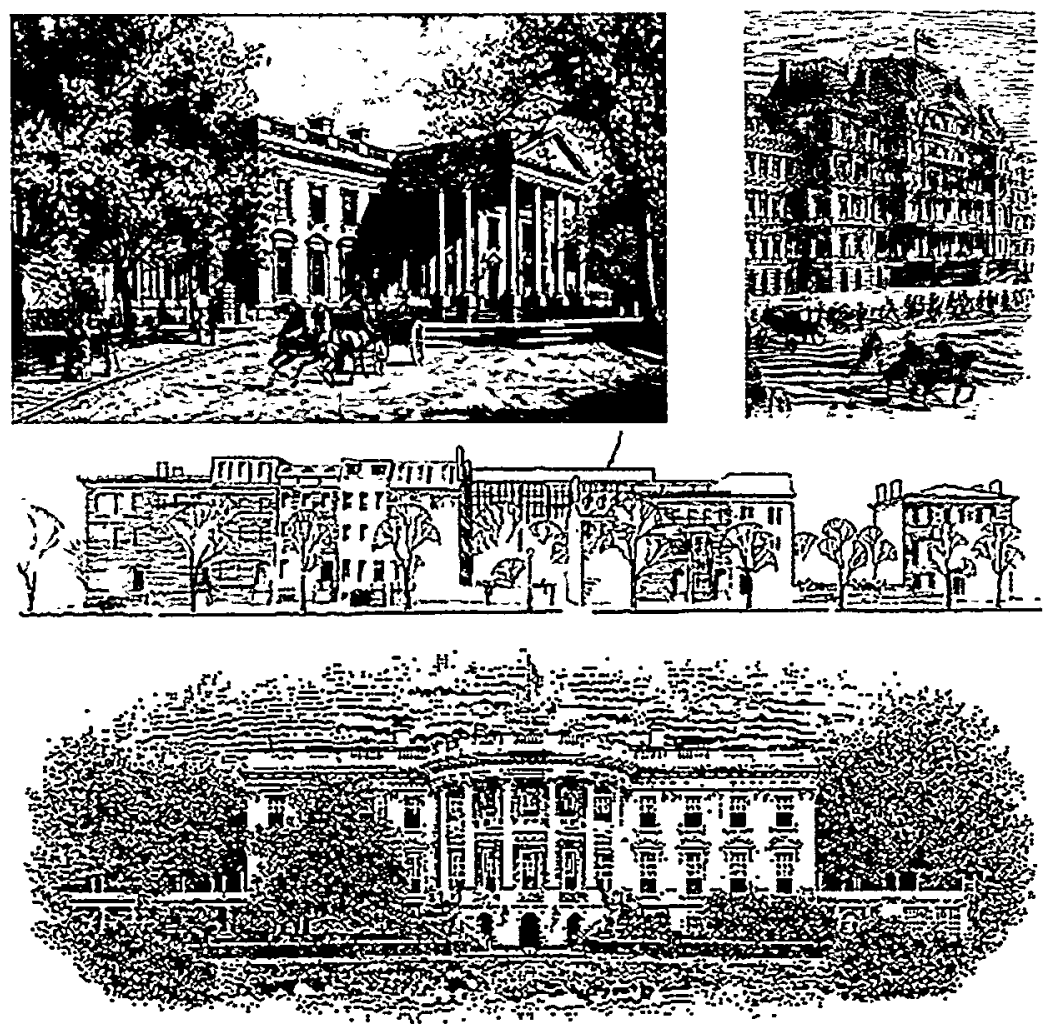


\section{The Greening of the White House...}

\section{An Introduction}

The White House, which recently celebrated its 200th birthday, has a long tradition of demonstrating technological innovation. In keeping with that tradition, President Clinton announced the Greening of the White House Initiative on Earth Day 1993. The initiative improves the energy and environmental performance of the White House complex by identifying opportunities to reduce waste, lower energy use, and make an appropriate use of renewable resources, all while improving indoor air quality and building comfort.

This report on President Clinton's legacy of greening at the White House White House Greening measures completed since 1993 have saved almost $\$ 1.4$ million to date and are now avoiding at least 845 metric tons of carbon every year. summarizes progress made to date and gives an overview of new opportunities identified during the past year. It also includes an environmental history of the White House and a short tour of the buildings that make up the White House complex. Over the past five years, this initiative has involved hundreds of dedicated people from both within and outside government. A description of how they worked together to develop and implement the Greening Plan is also included in this report.

Many of the steps identified during the first two years of the Greening Initiative were implemented. The Second Annual Report, issued in March 1996, estimated savings of more than $\$ 150,000$ per year in energy and water costs, landscaping expenses, and expenditures associated with solid waste. White House Greening measures

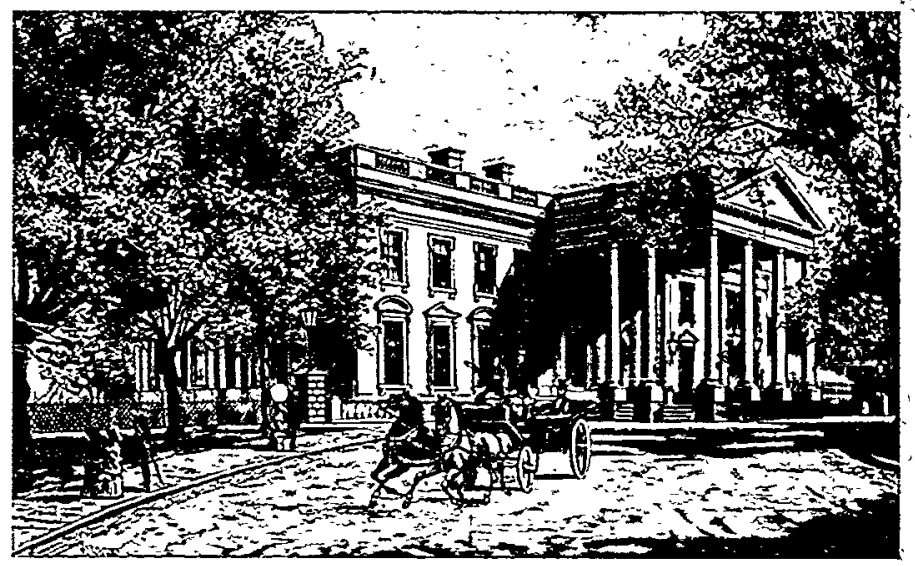
completed since 1996 are saving an additional $\$ 150,000$ each year, for a total of approximately $\$ 300,000$ annually. These new projects, together with the original measures, are also avoiding atmospheric emissions of at least 845 metric tons of carbon every year.

The Greening Plan can decrease White House energy and water consumption by 50 percent or more. It also supports President Clinton's leadership role in protecting the environment. The Greening of the White House project creates an environmentally sustainable White House and a world-class environmental showcase.

The White House has been described as the house of the people. In that

The Greening Plan can cut

White House resource consumption by 50 percent or more. sense, this work is not just about the White House, it is about your house. Many of the steps identified and implemented in this report make good economic and environmental sense for many Americans. Hopefully this report will provide you with the ideas and inspiration to make your home, office, or business more energy efficient, environmentally sound, and comfortable. 


\section{What are the White House "Greening Measures"?}

These short descriptions identify what steps the Greening Team have taken in the past and are currently considering to reduce energy and waste in the White House complex. In the coming pages, a "tour" is given of each building in the complex, including a short history and more details on the following measures.

These symbols will help you quickly identify what measures were implemented.
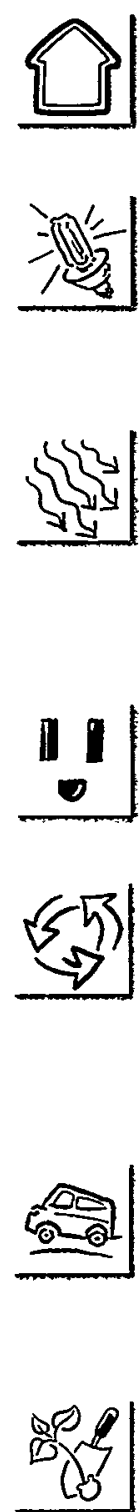

Building Envelope: A significant amount of energy is lost through the roof, windows, and walls of buildings, so those areas were analyzed for options to increase efficiency.

Lighting: Energy-saving light bulbs were installed wherever possible, and steps were taken to ensure lights are turned off in rooms that are not in use. Maximizing the use of natural light was a priority, because it's free and more visually pleasing.

Heating, Ventilation, and Air Conditioning (HVAC): Measures were sought to reduce the amount of energy used to heat and cool the buildings while simultaneously increasing occupant comfort. Improving indoor air quality and reducing the use of paint with volatile organic compounds are also major goals.

Plug Loads: Energy-saving office equipment was installed, and refrigerators and coolers were replaced with more energy-efficient models.

Waste: After analyzing the waste being generated, a comprehensive recycling program began for aluminum, glass, paper, newsprint, furniture, batteries, fluorescent lamps, paint solvents, and laser printer cartridges. Organic yard waste is recycled at an off-site composting facility.

Vehicles: Many leased vehicles accept cleaner-burning alternative fuels, and the White House is participating in a pilot program to test electric vehicles. Also, many employees use public transportation to decrease the use of automobiles.

Landscaping: Methods to reduce unnecessary water and pesticide use and increase organic fertilizers on the grounds of the complex were analyzed. 


\section{Take the}

\section{Greening of the White House Tour}

You are invited to take a tour of the White House complex to learn more about the historic buildings and take a closer look at the energy and waste reduction measures that make up the Greening of the White House Initiative.

As you visit the various buildings, the Greening measures will be discussed in greater detail and you will learn what has been accomplished and what is planned for the future. Keep in mind that much of what was done used existing technologies that are now applicable to a wide range of buildings, including your own home or office.

The tour begins in the White House, proceeds to the Old Executive Office Building, and then to the townhouses on Jackson Place.

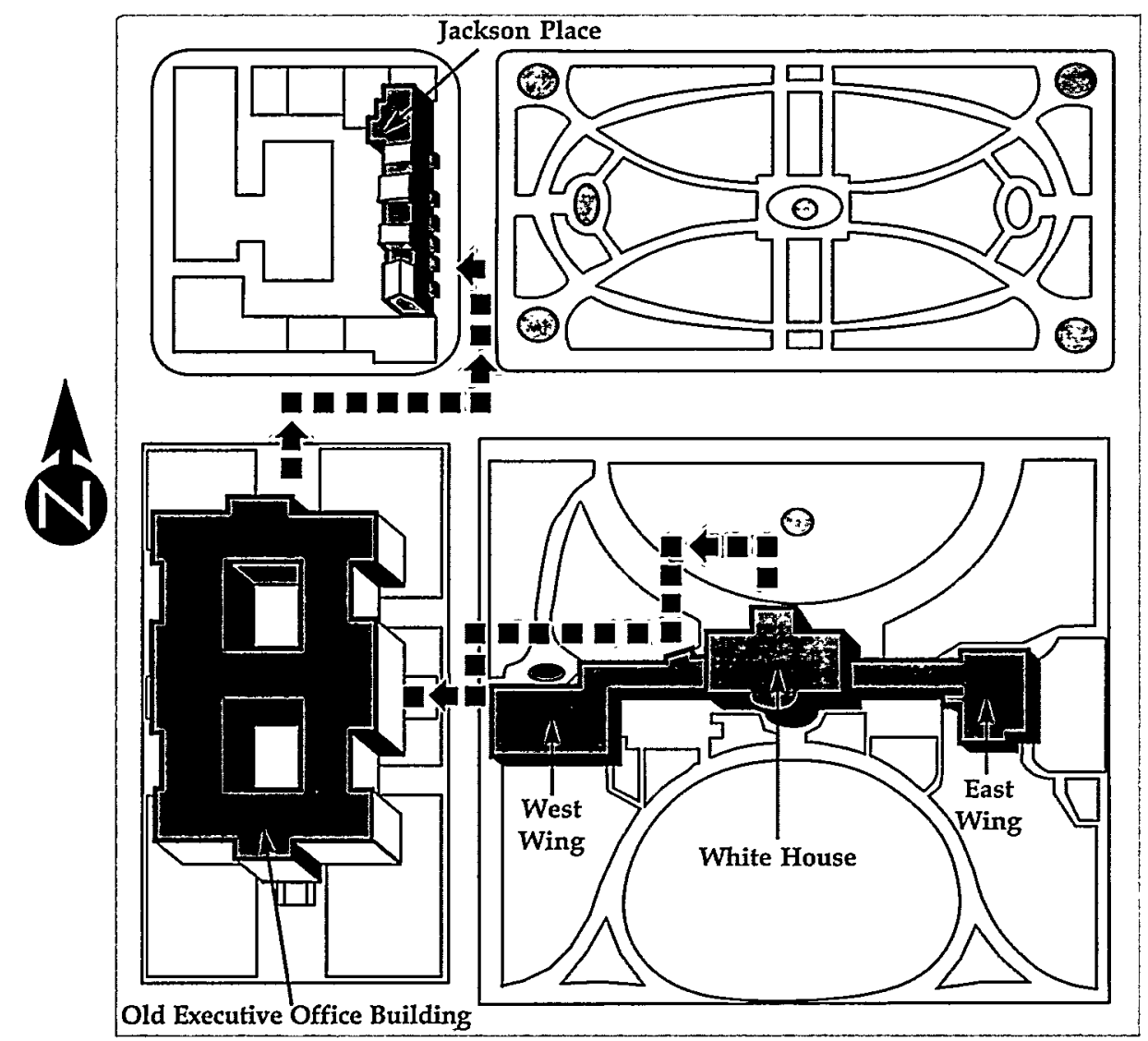

\section{The multibuilding}

White House complex encompasses about 800,000 square feet of space. 


\section{The White House}

Martin Van Buren, the first

President born in the

United States, installed the

first central heating system in the White House.
Besides being a home to the President and his family, the White House includes office space, a museum, ceremonial spaces used for visits and special events with dignitaries, a restaurant, and an 18-acre botanical garden. The White House is composed of three main sections: the Executive Residence, the East Wing, and the West Wing. The First Family lives on the second and third floors of the Executive Residence, which also contains space for guests. The ground floor is open to the public and is visited by more than a million people annually. From the central heating system in the mid 1800s to the plumbing, gas lighting, elevators, air conditioning, solar panels, and the first generation compact fluorescent lamps added during the Bush Administration, the White House frequently has been a showcase for innovations.

James Hoban, an Irishman, designed and began building the Executive Residence in 1792. George Washington laid the cornerstone of the building, but John Adams was the first President to occupy the building, in 1800. The White House is oriented on an east-west axis, allowing for maximum use of the sun for lighting and heating. The building was lit by sunlight during the day, with candles and lard-oil lamps used at night. Gas lighting was added in 1848, and wiring for electrical lighting soon followed after Thomas Edison perfected the light bulb. Today sunlight still provides light for most of the day.

Despite the ample sunlight and numerous fireplaces, heating remained a problem for a long time. A coal-fired furnace to heat the dining room was installed for President Adams, but when the White House was destroyed by the British in the War of 1812, the furnace was not replaced. Later, frustrated by the inadequate heating, President Andrew Jackson remarked, "Hell itself couldn't heat that corner." President Martin Van Buren had the first central heating system installed. The air, heated by burning coal, rose through flues and chambers into many of the rooms. The White House was one of the first houses in the country to have running water when plumbing was installed in the 1830s. In 1853, during Franklin Pierce's presidency, the heating system was changed to circulate heated water in pipes. This improved indoor air quality and burned less coal. Eventually the system was switched to 
steam. In the 1970s, during the Carter Administration, solar panels were installed to heat the water for the Navy Mess, but the panels didn't function as well as hoped, so President Reagan had them removed.

In the summer, the building's position on the edge of a hill, combined with large windows and high ceilings, maximized the cooling power of breezes. The first attempt at central air conditioning was in

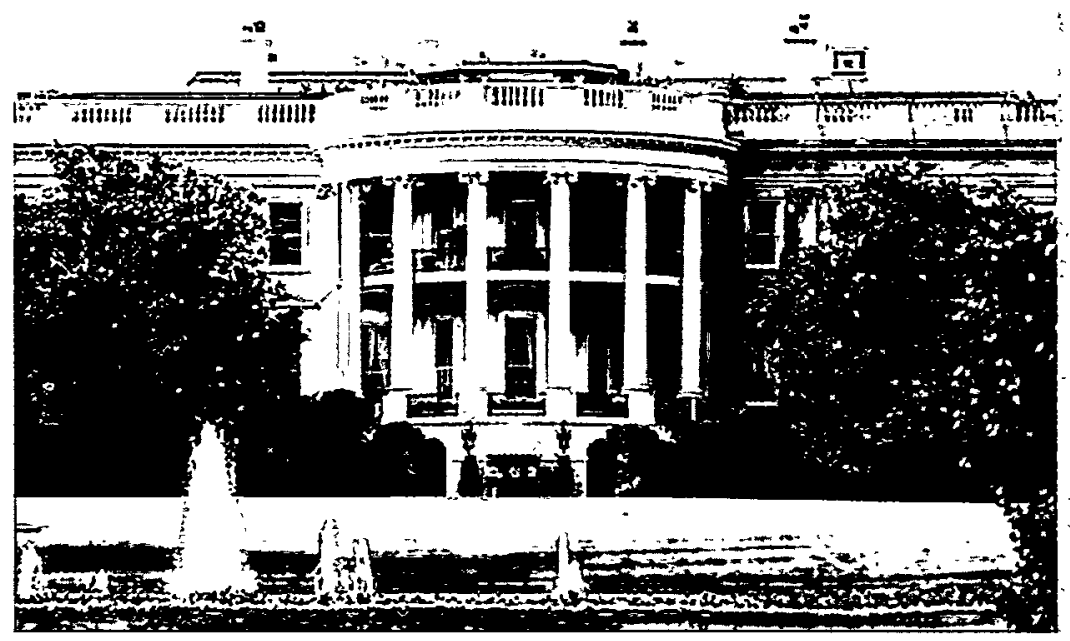
1909 with a system in which fans blew air across ice bins placed in the attic. This system did not work, but during the Truman presidency an air conditioning system was installed that is still in use, with new controls and chillers recently added.

The President and his closest staff work in the West Wing, which contains the Oval Office, meeting spaces, White House media office, and the Navy Dining Mess. The oldest portion of the West Wing was built originally as a stable during the presidency of Thomas Jefferson. At the beginning of the 20th century, the extensive conservatories on the site were demolished to make way for office space. The West Wing was expanded again in the 1930s.

The East Wing was intended to be a museum, but when construction began in 1941, the outbreak of World War II forced most of the space to be used for other purposes. Today, the East Wing contains mostly office space, including the First Lady's, and a theater. Tour visitors enter the White House through the East Wing and walk down a corridor looking out into the Jacqueline Kennedy Garden before entering the ground floor of the Executive Residence.

The landscaping and use of the White House grounds have changed often over the last two centuries. Past activities included livestock grazing and military drills. Some former Presidents planted trees from their home States on the grounds, many of which did not survive in Washington's climate. The National Park Service and the General Services Administration, which are responsible for maintaining the grounds and buildings, now plant only species that are native to Washington and give preference to organic practices whenever possible.

The current size and configuration of the grounds were arrived at around the beginning of this century. Today's many uses include treaty events, celebrations, and the traditional Easter Egg Roll. Television crews use a space just to the north of the West Wing to film segments of their White House news stories. So many events occur on the South Lawn that the sod in this area must be replaced several times a year. In addition to the well-known Rose and Jacqueline Kennedy Gardens, the grounds include a tennis court, a swimming pool, a running track made from recycled rubber, and the Grandchildren's Garden.

7,000 hard-boiled eggs were used in the 1999 Easter Egg Roll. 


\section{White House Greening Activities}

\section{Completed}
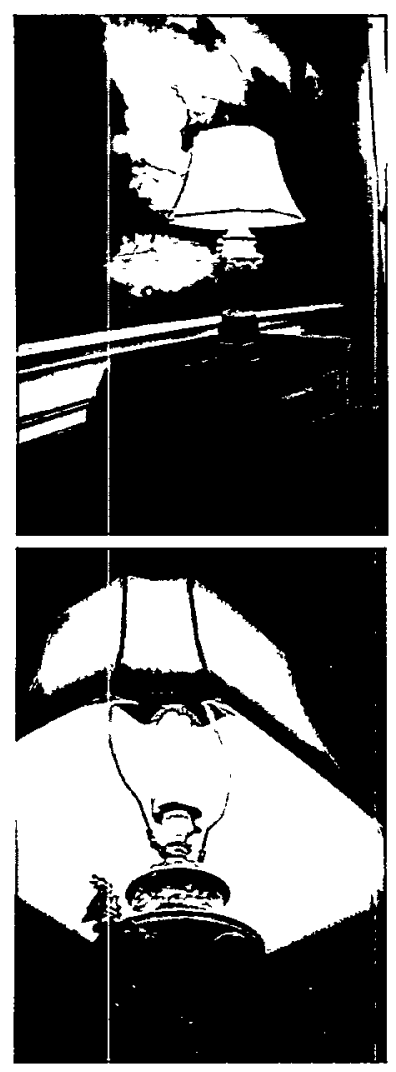

Using compact

fluorescent bulbs instead of incandescent light bulbs saves $\$ 22,000$ each year throughout the White House complex.

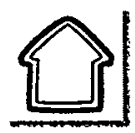

- The roof of the White House was replaced to improve the thermal integrity of the building shell.

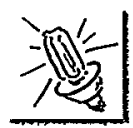

- Incandescent table lamp bulbs in the White House were replaced with compact fluorescent bulbs where possible, saving 1,600 kilowatt-hours per year. Only 5 percent of the bulbs weren't replaced due to the historic character of the fixtures and security concerns.

- Exterior flood lighting was replaced with energy-efficient halogen lighting in 1994. The halogen spotlights are controlled by timers that turn off the lights after 11 p.m., reducing energy use for exterior lighting by 60 percent.

- Halogen lights were installed in the coolers for the flower shop and kitchen in 1998.

- In 1995 (East Wing) and 1997 (West Wing), T-12 fluorescent tube lamps were replaced with more efficient $\mathrm{T}-8$ fixtures and electronic ballasts.

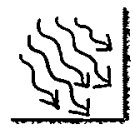

- In 1994, a chlorofluorocarbon (CFC) management system was put in place.

- A preventive maintenance program for kitchen freezer CFC leaks was instituted in 1994.

- Chiller CFC recycling/recovery/reclamation machines meet all applicable regulations. All CFC technicians were certified by the Environmental Protection Agency. 
- Installation of a new HVAC system in the Executive Residence was completed in January 1999. The chillers were replaced with highefficiency units that don't use CFCs. This project is expected to save 400,000 kilowatt-hours of electricity, 24,000 gallons of water, and $\$ 32,000$ per year.

- New insulation is being installed on all pipes as part of a larger asbestos abatement program begun in 1998.

- Ninety percent of the steam traps have been replaced to prevent steam loss.

- A no-smoking policy continues throughout the White House, improving indoor air quality.

- A new Park Service paint shop was completed in 1995 to improve indoor air quality, and a more efficient paint sprayer was installed in January 1999.

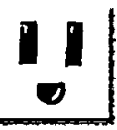

- The old coolers and refrigerators in the kitchen and flower shop of the Executive Residence have been replaced with more efficient units.

- The first high-efficiency (Golden Carrot) refrigerator was installed in 1994. At that time, the model exceeded industry standards for energy efficiency by 30 percent.

- Since September 1995, 99 percent of the computers, printers, copiers, and fax machines purchased have been efficient ENERGY STAR® models. These units consume 50 to 60 percent less energy than comparable models.

- Staff are required to turn computers off after work to save energy and promote security.

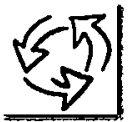

- Due to security requirements, most documents are shredded into fibers too short for traditional recycling. Since July 1998, this material has been sent to an off-site composting facility where it is mixed with yard trimmings to make a compost product called LEAFGRO.

LEAFGRO, in turn, is used as compost on White House grounds.

LEAFGRO is also available for purchase commercially. 


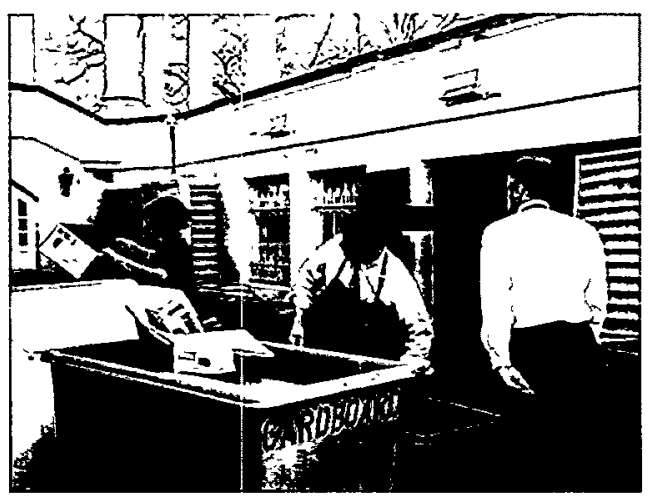

Recycling
- An ongoing project began in 1993 to educate staff and set internal policy to reduce paper consumption, limit the use of disposables, conserve office supplies, and eliminate unnecessary items.

- The staff purchases recycled paper including copier paper containing 30 percent of post-consumer products and stationery with 20 percent of such products. The library staff sends newspapers to a recycling facility once the microfilm version arrives. Monthly accounting reports are copied on both sides and personnel, procurement, and travel forms are being automated.

- Used furniture is refurbished to avoid cutting new wood and manufacturing other materials to make new furniture.

- Inks that contain biodegradable vegetable ingredients are used for printing, decreasing the environmental impact related to the disposal of printed items.

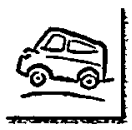

- The White House has a contract with DaimlerChrysler to supply 75 percent of its fleet with alternative-fuel vehicles. Currently, these are flexible-fuel ethanol vehicles.

- In August 1998, the White House participated in a pilot program sponsored by the Potomac Electric Power Company and the Department of Energy to test Ford's electric 1998 Ranger pickup truck.

- Metrochek, a transit subsidy program, encourages eligible employees to use public transportation and reduce the environmental impact associated with the use of automobiles. Recently, the pool of eligible employees was significantly expanded to enhance the environmental benefits of the Metrochek program.

- A shuttle service is provided for official travel to Capitol Hill, thereby minimizing the need for extra trips by automobile. 


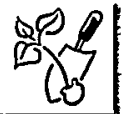

- Pesticide use has been reduced 80 percent by eliminating blanket sprays and improving pest management.

- In 1994, sprinkler heads were adjusted and/or replaced and watering was switched to the early morning, saving 15,000 gallons in one year.

- Since 1995, native plants have been planted in place of nonnative species.

- Trimmings and yard waste from the 18 acres of grounds are composted off-site and returned for use as soil amendments.

\section{Recommended/Planned}

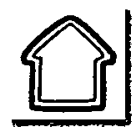

- The Solarium and Greenhouse are being redesigned to include energy-efficient glazings.

- Replace the existing electric swimming pool heaters with a solar water heater or natural gas-fired heater, saving about $\$ 1,120$ per year, and implement conservation measures such as covering the pool when it's not in use.

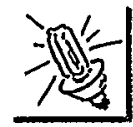

- The Park Service is awaiting funding to rehabilitate the visitors entrance building near the East Wing. Recommendations to upgrade the fluorescent lighting from $\mathrm{T}-12$ bulbs to $\mathrm{T}-8$ bulbs and electronic ballasts will be incorporated into the project.

- Install photovoltaic-powered lighting for the Pennsylvania Avenue Park, and incorporate PV arrays into visitor kiosks to showcase the technology. Photovoltaics could provide enough energy to power the 40 -watt bulbs in each kiosk.
Adjusting and replacing sprinkler heads saved

15,000 gallons of water in one year.

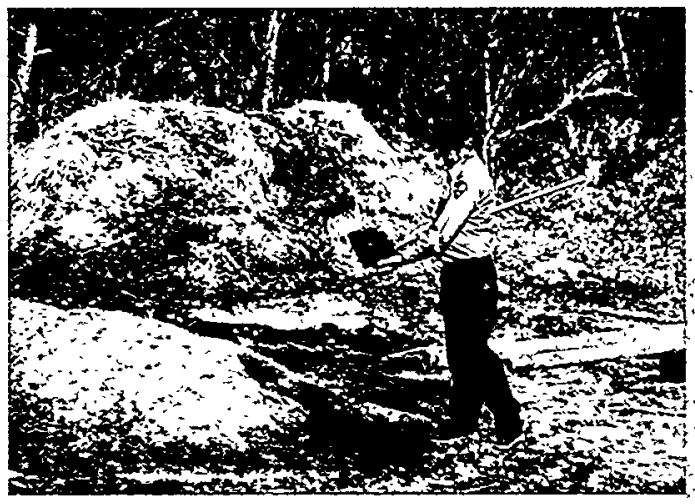

Composting
A solar water heater for the swimming pool could save more than $\$ 1,000$ per year. 
- Automatic controls will be used to reduce the energy use of lighting and take advantage of natural daylight in the East Wing visitors entrance building.

- Replace incandescent light bulbs in the paint shop with triplephosphor fluorescent lamps for improved color rendition.

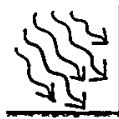

- An ozone-friendly non-chlorofluorocarbon ("non-CFC") airconditioning system for the East and West Wings of the White House is scheduled for completion during FY 2000.

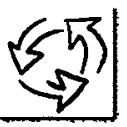

- Work with the EPA to establish a collection system to recycle nickel-cadmium batteries. 


\section{The Old Executive Office Building}

Located next to the White House, the Old Executive Office Building (OEOB) occupies a unique place in Washington's architectural history. The building's flamboyant French Second Empire design stood in stark contrast to its Greek Revival neighbors. When completed after 17 years of construction in 1888, the OEOB was the largest office building in Washington with $41 / 2$-foot-thick granite walls, 16 -foot ceilings, 2 miles of black and white marble tile corridors, and more than 550 offices in 600,000 square feet of space. The building has two large internal courtyards and was originally designed to use daylight and natural ventilation. In 1969, the OEOB was designated a National Historical Landmark, and in 1972 it was placed on the National Register of Historic Places.

The building was designed soon after the discovery of carbon dioxide, leading to the development of an intricate ventilation system. Air channels were built throughout the walls, allowing fresh air to enter rooms through slots under the windows. At each corner, stained glass domes top open stairwells. Hot air would rise into the domes and exhaust through vents into glazed skylit spaces, creating negative pressure that pulled air through the rest of the building.

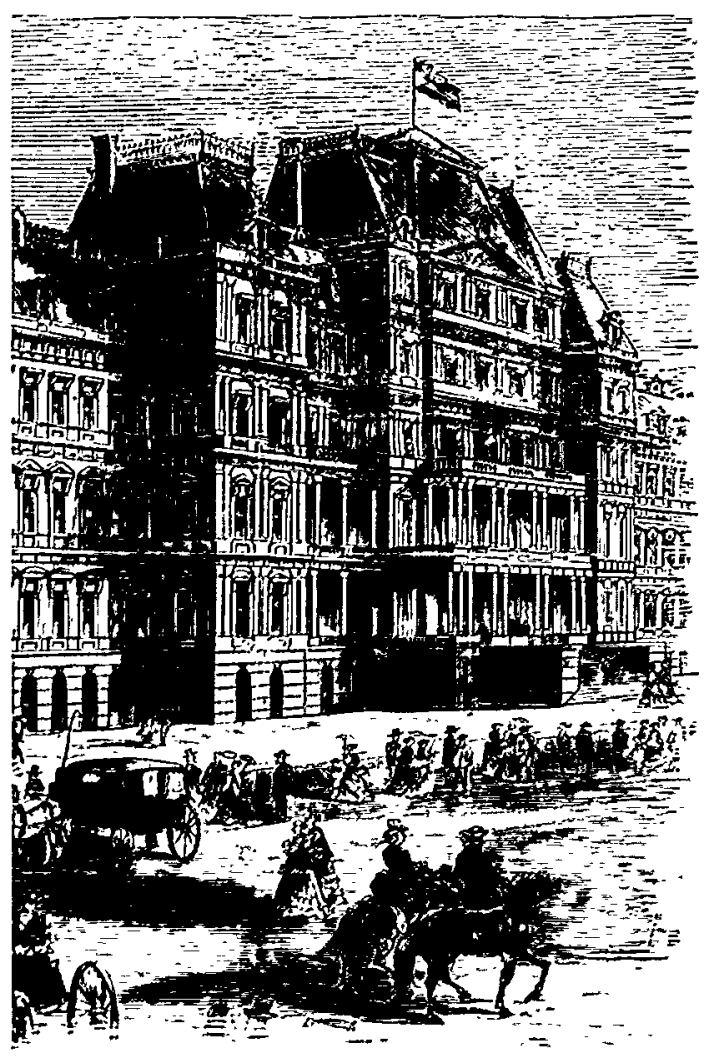

The ventilation system was gradually disabled over the years. Today's cooling system consists of 782 window air conditioners, 100 package units, and three chillers. An exterior renovation begun during the Reagan Administration restored the skylights to their original function.

Originally designed to house the State, Navy, and War Departments, it today contains the Vice President's ceremonial office and more than 25 agencies within the Executive Office of the President. The building also contains the historic Indian Treaty Room, two libraries, a small gymnasium, a two-lane bowling alley, a paint shop, and a furniture repair shop.
The Old Executive

Office Building is the largest granite building in the world.

President Taft allowed the family cow, Pauline, to graze on the south lawn of the OEOB. 


\section{Old Executive Office Building \\ Greening Activities}

\section{Completed}

The building's first light bulb was installed in 1893.

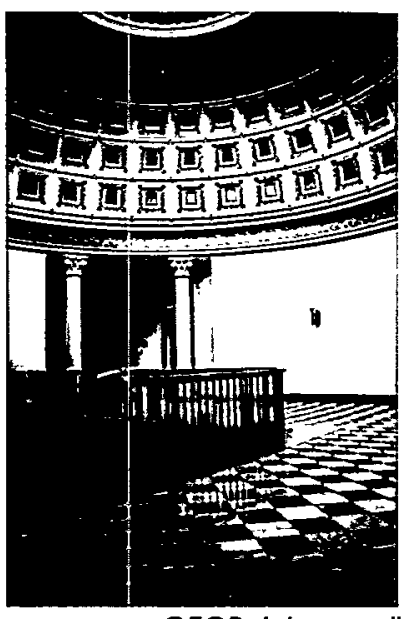

OEOB skylit stainvell

The lighting upgrades in the OEOB have reduced the building's total energy load by more than 12 percent.<smiles>c1ccc(C23CC4CC(C2)C(C4)C3)cc1</smiles>

- Ninety-eight percent of the windows were replaced with energyefficient double-paned units. The remaining 2 percent are not doublepaned because of historic considerations.

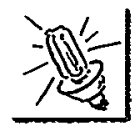

- The 1,600 incandescent light bulbs in corridor fixtures were replaced with energy-efficient compact fluorescents, saving more than $\$ 20,000$ each year and avoiding 100 metric tons of greenhouse gases.

- More than 90 percent of all overhead lighting has been upgraded with energy-efficient T-8 fluorescent tubes and electronic ballasts. Security concerns have prevented replacing the remaining 10 percent. This project cut lighting energy use by almost 70 percent and paid for itself in three years by saving nearly $\$ 100,000$ annually.

- Motion detectors were installed in the bathrooms, copy rooms, and conference rooms to shut off lights automatically when rooms are unoccupied, saving about $\$ 6,000$ per year.

- In 1994, the mercury vapor lighting in the Indian Treaty Room was replaced with more efficient metal halide lights, which provide 35 percent more light and dramatically improve color rendition in this historic meeting place.

- Most table lamp bulbs were replaced with compact fluorescent bulbs. Only 2 percent were not replaced, due to security reasons.

- In 1995, the historic skylights were rehabilitated, which increased daylighting and restored the original historical appearance.

- Outdoor lighting was programmed in 1998 to turn off after 11 p.m., reducing energy consumption by 60 percent. 
- Converting to light-emitting diode (LED) exit signs reduced annual electricity use by 280 kilowatt-hours per sign. This is a savings of approximately $\$ 25$ in energy costs for each sign. Maintenance is also decreased dramatically.

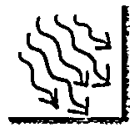

- Eighty-five percent of the window air conditioning units have been replaced with more efficient models meeting the Department of Energy's and EPA's ENERGY STAR® requirements. This ongoing retrofit is saving more than $\$ 4,500$ in electricity costs per year.

- Timers have been installed on a large number of window air conditioner units to turn them off between 10 p.m. and 5 a.m.

- New R-19 fiberglass insulation was installed on steam pipes as part of an asbestos abatement program.

- A preventive maintenance program for ozone-depleting CFCs from kitchen freezer leaks was instituted in 1994.

- Chiller CFC recycling/recovery/reclamation machines met regulations in 1994. All CFC technicians were EPA-certified by 1994.

- In 1994, the chiller system was modified to recirculate cooling water instead of wasting it.

- The no-smoking policy within the White House complex continues, improving indoor air quality.

- Begun in 1995, 60 percent of the rooms have been painted with paint low in volatile organic compounds. The remaining rooms are painted with oil-based paints due to historic considerations.

\section{!'}

- Since 1995, 99 percent of the computers, printers, copiers, and fax machines purchased have been efficient ENERGY STAR® models. These units consume 50 to 60 percent less energy.

- Staff are required to turn computers off after work to save energy and promote security.

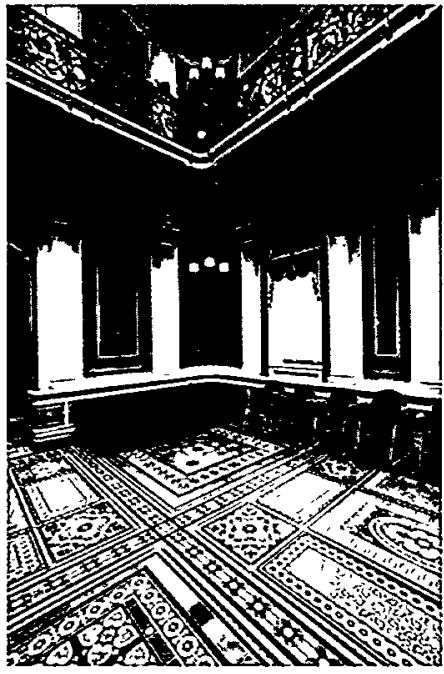

Metal halide lighting improved lighting levels in the Indian Treaty Room by 35 percent with no additional energy use.
New air conditioners save more than $\$ 4,500$ in electricity costs per year. 
- An ongoing project began in 1993 to educate staff and set internal policy to reduce paper consumption, limit the use of disposable products, conserve office supplies, and eliminate unnecessary items.

- The staff purchases recycled paper including copier paper containing 30 percent of post-consumer products and stationery with 20 percent of such products. The library staff sends newspapers to a recycling facility once the microfilm version arrives. Monthly accounting reports are copied on both sides and personnel, procurement, and travel forms are being automated.

- Used furniture is refurbished to avoid cutting new wood and manufacturing other materials to make new furniture.

- Inks that contain biodegradable vegetable ingredients are used for printing, decreasing the environmental impact related to the disposal of printed items.

- In 1994, an agreement was completed to ensure that all hazardous waste is handled in accordance with internal procedures that comply with Resource Conservation and Recovery Act regulations.

- All hazardous waste was consolidated in an OEOB storage cabinet in 1993.

- Hazardous waste is inspected weekly, and has undergone a chemical inventory. Polychlorinated biphenyl (PCB) records were consolidated in 1993.

- Since 1994, staff working near PCB-contaminated transformers wear protective clothing, and transformers are periodically drained and filled with non-PCB fluid.

Pesticides have been reduced by 80 percent.

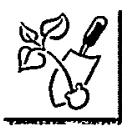

- The GSA reduced fertilizer consumption by one-third by using mulching mowers and increasing the use of compost.

- Pesticide use has been reduced 80 percent by eliminating blanket sprays and improving pest management. 
- Seasonal flowerbeds, which have high maintenance costs, were replaced in 1998 with perennials and shrubs.

- Water conservation devices were installed in restrooms, kitchens, and other areas in 1994. Combined with adjusting and replacing sprinkler heads and watering the landscape in the morning, 15,000 fewer gallons of water were used in 1995.

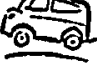

- Metrochek, a transit subsidy program, encourages eligible employees to use public transportation and reduce the environmental impact associated with the use of automobiles.

Recently, the pool of eligible employees was significantly expanded to enhance the environmental benefits of the Metrochek program.

- A shuttle service is provided for official travel to Capitol Hill thereby minimizing the need for extra trips by automobile.

\section{Recommended/Planned}

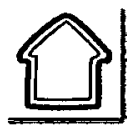

- Certify the OEOB as an EPA/DOE ENERGX STAR® building, signifying excellence in energy performance. This benchmark recognizes the top 25 percent energy-efficient commercial office buildings.

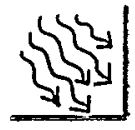

- More efficient chillers are being designed, and are to be installed during summer 2000.

- Install more window air conditioning unit timers as budget allows. 
- Upgrade the document shredder to improve air quality. The current shredder creates a large amount of dust when operating.

- A long-term project, currently in its planning stages, is the elimination of single window air conditioning in favor of a nonCFC central air conditioning system.

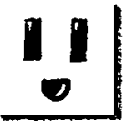

- Install the first ENERGY STAR $\circledast$ labeled vending machine in the OEOB's snack bar as soon as it becomes available. The ENERGY STAR ${ }^{\circledR}$ vending machine program is still in development; labeled products will likely be available in 2001. DOE and EPA will work with GSA's concession's office to install the appropriate ENERGY STAR® labeled equipment.

- The renovation of the electrical distribution system is scheduled for FY 2002 and FY 2003. This includes the replacement of transformers, antiquated wiring systems, and electrical distribution equipment.

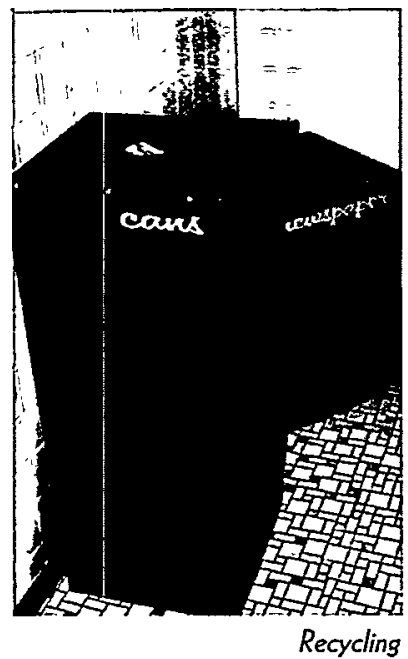

- Improve the labeling system of the building's recycling containers.

- Work with the EPA to establish a collection system to recycle nickel-cadmium batteries.

- Initiate a pilot project to test bio-based products (tableware, plates, and garbage bags) in the cafeteria. 


\section{Jackson Place}

The Jackson Place townhouses are located along the west side of Lafayette Park north of the White House. The tract of land was originally known as "Jamaica," and records show John Pierce first owned it in 1685. The Federal Government purchased the land in 1792 as part of the new District of Columbia.

By 1803, the land had been designated as a public area, known first as President's Square or the Common and, after 1825, as Lafayette Square. Gravel carriageways were laid out along the west and east sides of the square, and by 1824 an old ferry road along the north side of the square had become H Street. Both Charles Bulfinch, a famous architect of government buildings who also finished the Capitol Building, and Andrew Jackson drew plans for improving the grounds in Lafayette Square. In 1858, the carriageways were officially named Jackson Place and Madison Place. During the 19th century, the land gradually turned from a neglected common to an attractive urban park. The neighborhood remained essentially residential from the 1820 s until the early 20th century, when several row houses were adapted to small offices and others were replaced with larger structures for offices.

During the Eisenhower Administration, plans to demolish the existing structures and construct new Federal office buildings on the square ignited community opposition.

For the past 30 years, the townhouses on Jackson Place have provided space for White House offices and special projects related to the Executive Office of the President. Presently, Jackson Place is home to the White House Council on Environmental Quality, the White House Climate Change Task Force, the Millennium Program, the Office of National AIDS Policy, the White House Historical Society, and a conference center. In 1998, the buildings were added to the Greening of the White House Initiative and underwent extensive audits to identify opportunities to reduce energy use and waste, as well as improve indoor air quality.

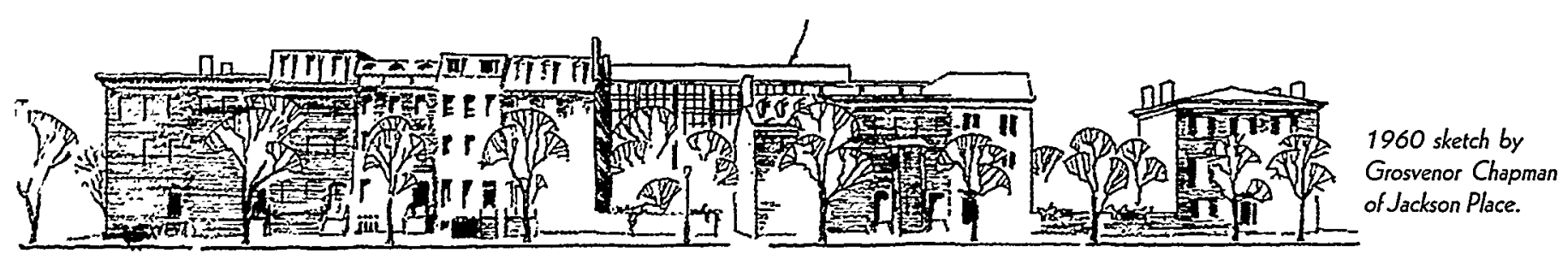




\section{Jackson Place}

\section{Greening Activities}

\section{A Department of Energy audit revealed the potential to save} $\$ 135,000$ per year.

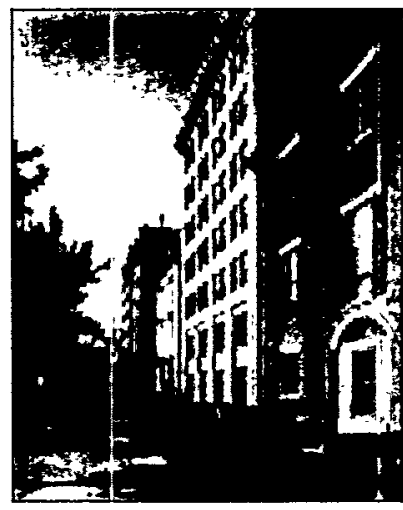

Jackson Place, ca. 1920. By Theodor Horydczak.
Although the Jackson Place buildings did not join the Greening Initiative until 1998, several projects have taken place since 1993 through general greening policies affecting the entire White House complex. For example, since September 1995, virtually all office equipment purchased meet ENERGY STARß standards. And in 1993, as part of an ongoing project, the staff was mandated to reduce resource consumption and waste generation. A Department of Energy audit was one of the first steps of the Jackson Place greening process, and the audit discovered potential annual energy savings of $\$ 135,000$. The General Services Administration is funding a comprehensive engineering and architectural study of Jackson Place to explore more carefully the options presented in the DOE audit.

An indoor air quality audit performed in 1998 by the Environmental Protection Agency determined the condition of key factors that affect indoor air quality. These factors include measurements of ventilation and radon, and indicators of potential problems from pollutants such as mold and mildew; pest detritus; lead-based paint; and gaseous emissions from building materials, furnishings, and housekeeping supplies. The audit revealed several operation and maintenance actions that could result in a healthier and more productive work environment, as well as reduced energy consumption.

\section{Recommended/Planned}

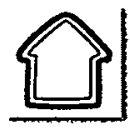

- Replace all windows with double-glazed windows meeting the appearance standards of historical preservation (window retrofits to begin in April 2000).

- Install weather stripping to reduce air infiltration. Reducing heat loss and gain could save $\$ 13,000$ per year. 
- Finish converting T-12 fluorescent tubes to more efficient T-8 fixtures and electronic ballasts.

- Replace incandescent bulbs in table and desk lamps with compact fluorescent bulbs.

Ceiling fans could help save more than $\$ 2,000$ per year.

- Install motion sensors in areas with sporadic activity and maintain constant light levels in rooms with dimmable lighting systems. These measures, taking into account the reduced heat gain during winter, would produce net savings of $\$ 3,000$ per year.

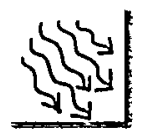

- Install ceiling fans as a near-term solution to destratify the air in the high-ceiling rooms. Thermostats could then be set lower, saving $\$ 2,300$ per year.

- Correct problems with makeup air systems to improve air quality, comfort, and energy efficiency.

- A feasibility study is under way to investigate installing highpressure HVAC lines, which will resolve heating and cooling issues on upper floors while preserving the historical character of the rooms. Energy savings from this new technology are estimated to be around 30 percent.

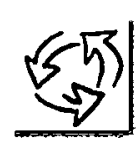

- Improve the labeling system of the building's recycling containers.

- Work with the EPA to establish a collection system to recycle nickel-cadmium batteries. 


\section{The Bottom Line - Energy Efficiency Measures in Place}

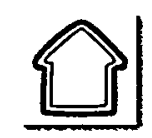

Building Envelope

Replace Executive Residence roof with lead-coated copper roof installed over rigid board thermal insulation

Replace $98 \%$ of windows in OEOB with double-paned units and low-emissitivity (low-E) film.

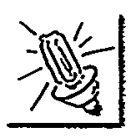

\section{Lighting}

Replace incandescent bulbs in table lamps

and corridor lighting with compact fluorescent bulbs (White House, OEOB)

Replace exterior facade lighting with halogen fixtures (White House)

Retrofit fluorescent fixtures in service areas using T-8 bulbs, electronic ballasts, and controls; halogen lighting in coolers (White House)

Replace 23 300-watt incandescent bulbs in paint shop with triple-phosphor fluorescent lamps (White House)

Replace T-12 bulbs with T-8 tubes, electronic ballasts, and reflectors (East and West Wings, OEOB)

Retrofit mercury vapor with metal halide lights in Indian Treaty Room (OEOB)

Install motion sensors in the restrooms, copy rooms, and conference rooms (OEOB)

$36,000 \mathrm{kWh}$ (123 million Btu)

$350,000 \mathrm{kWh}$

(1.2 billion Btu)

$111,000 \mathrm{kWh}$

(379 million Btu)

$14,400 \mathrm{kWh}$

(49 million Btu)

$1,634,644 \mathrm{kWh}$ (5,577 million Btu)

$35 \%$ more light

$100,000 \mathrm{kWh}$ (341 million Btu)
Carbon

Emissions

Avoided

(Tons)

1

$\$ 520$

$\$ 8,000$

11

100

10

35

4

$\$ 98,078$

515

$\$ 0$

0

$\$ 6,054$ 
Install new HVAC system in the White House using HCF-134 (non-CFC) coolant (Executive Residence)

Install R-19 insulation on all exposed steam lines and replace steam traps on an ongoing basis (East and West Wing, OEOB)

Upgrade 208V window unit air conditioners beyond 9.5 energy efficiency ratio level. Install timers on all window air conditioning units to turn off from 10 p.m. to 5 a.m. (OEOB)

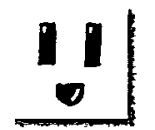

Plug Loads

Install superefficient "Golden Carrot" refrigerator in the Executive Residence

Install more efficient coolers in kitchen and flower shop in the Executive Residence

Initiate policy to purchase only ENERGY STAR® Office equipment (East and West Wings, OEOB)

Energy Efficiency Bottom Line Other Greening Savings

(Waste reduction, vehicles, water conservation, landscaping, operations and maintenance)

\section{Total Bottom Line}

\begin{tabular}{c|c|c}
$\begin{array}{c}\text { Annual Energy } \\
\text { Savings }\end{array}$ & $\begin{array}{c}\text { Annual Cost } \\
\text { Savings (\$) }\end{array}$ & $\begin{array}{c}\text { Carbon } \\
\text { Emissions } \\
\text { Avoided } \\
\text { (Tons) }\end{array}$ \\
\hline $400,000 \mathrm{kWh}$ & $\$ 32,000$ & 116 \\
$(1.4$ billion Btu) & &
\end{tabular}

Steam line improvement measures are ongoing.

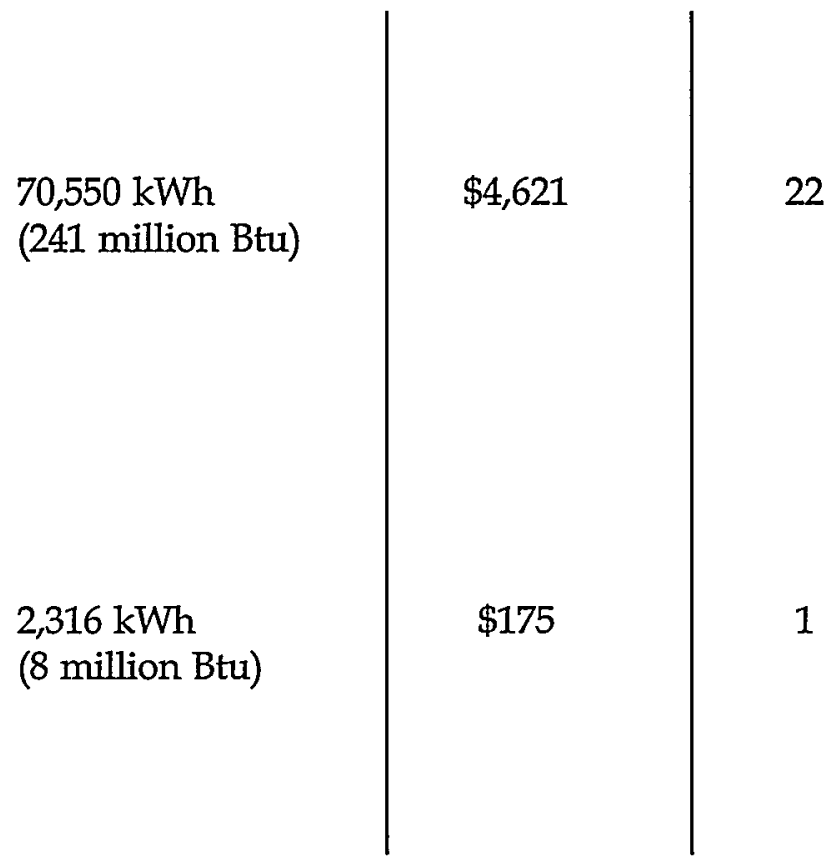

Reduce office equipment energy consumption $50-60 \%$.

9.8 billion Btu

$\$ 183,182$

845*

$\$ 300,182$

NOTE: Engineering estimates used for savings calculation for some measures.

*Avoiding 845 tons of carbon emissions is equivalent to removing 648 cars from the road for one year.

**An exact breakdown of the savings from these measures is unavailable. 


\section{Environmental Bottom Line}

Some of the measures taken in the course of the Greening of the White House cannot be quantified in terms of energy savings or reduced carbon emissions. However, the following activities have had a beneficial impact on the environment or will help popularize new environmentally friendly technologies.

\section{Waste}

All organic yard waste is recycled at an off-site composting facility.

The complex's recycling program includes aluminum, glass, paper, batteries, cardboard, newspaper, plastic, construction materials, furniture, fluorescent lamps, paint solvents, and laser printer toner cartridges.

Shredded paper is recycled into LEAFGRO soil complement for use in landscaping.

\section{Vehicles}

Seventy-five percent of the leased vehicles accept alternative fuels.

The complex participates in Potomac Electric Power Company's pilot program to test electric vehicles.

A transit subsidy program, Metrochek, encourages eligible employees to use public transportation. Also, a shuttle service is provided for official travel to Capitol Hill.

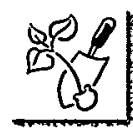

\section{Landscape}

Seasonal flowerbeds were replaced with perennials and shrubs.

Fertilizer use was reduced by one-third.

Pesticide use was reduced by 80 percent.

An emphasis is placed on native plant species. 
Appendix 


\section{The Greening Process}

The work performed as part of the Greening of the White House is based on a 1993 comprehensive energy and environmental audit by an intergovernmental team. The audit process included detailed reviews of building records and utility billings, research on building histories, and investigations of site conditions.

The energy audit team, led by the Department of Energy, included the Lawrence Berkeley National Laboratory; the National Renewable Energy Laboratory; and the Rocky Mountain Institute, which served as a technical advisor and as the liaison with the American Institute of Architects. This team gathered information on energy and water use, then analyzed the data to identify cost-effective, innovative techniques to save money and resources.

A charrette is an intensive design workshop with a set deadline, forcing participants to work quickly, creatively, and across disciplines.
The environmental audit team, led by the Environmental Protection Agency, included the General Services Administration, the District of Columbia's Regulatory Office, and the Institute for Environmental Auditing. This team examined the overall environmental performance of the complex and its compliance with various environmental acts and regulations, including the Resource Conservation and Recovery Act (RCRA) and the Federal Insecticide, Fungicide, and Rodenticide Act (FIFRA), among others. The White House was brought into full compliance with those regulations during the course of the greening improvements.

Audit information was used in a subsequent Feasibility Study that was sponsored by the American Institute of Architects (AIA) in July 1993. The Corporate Conservation Council of the National Wildlife Federation provided partial funding for the study. The AIA organized a design charrette composed of more than 90 experts from the Government and private sectors, the Rocky Mountain Institute, and the AIA National Committee on the Environment. They produced a model design process and expert recommendations, leading to an integrated approach to improve the White House's energy efficiency, performance, and environmental responsiveness. The recommendations emphasized cost-effectiveness and solutions using "state-of-theshelf" (commercially available) technologies. 
All of the early actions that could be accomplished easily and quickly, that had little or no implementation cost, and that were required for regulatory compliance, have been completed. One example is the "Golden Carrot" refrigerator in the Executive Residence. "Golden Carrot" refers to the design competition that resulted in the commercial production of a superefficient appliance designed to use 25 to 50 percent less energy than standard models and using no chlorofluorocarbons (CFCs).

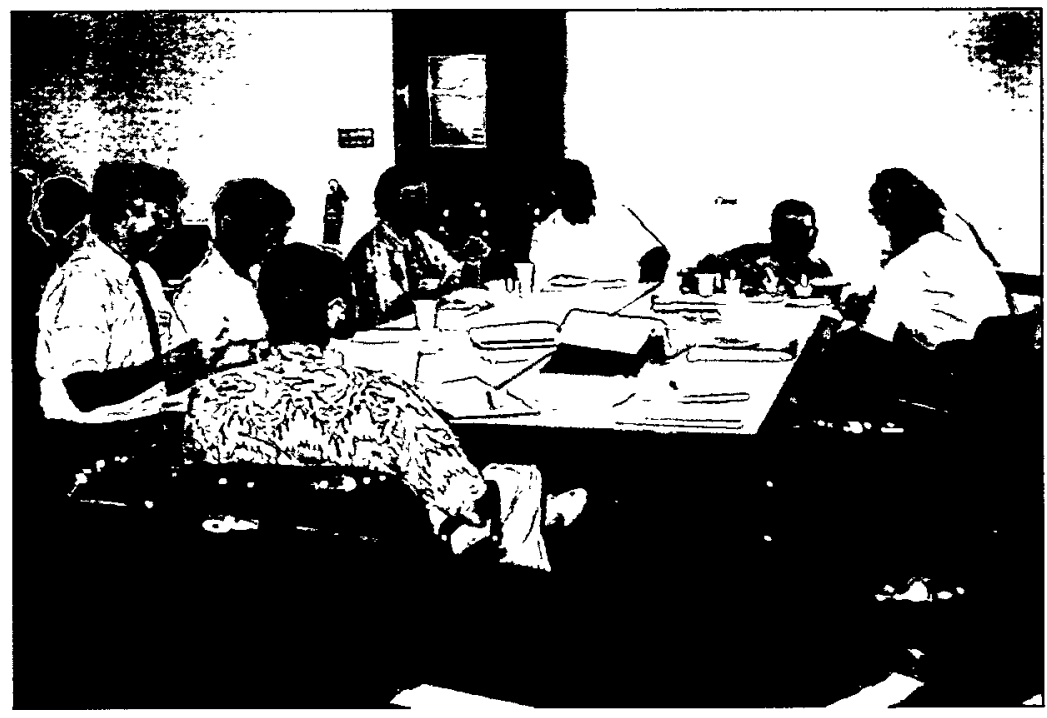

Long-term initiatives focus on goals rather than specific actions, ensuring that the greening measures become permanent. Operations, maintenance, and White House charrette. procurement practices are a few areas in which change can occur through increasing environmental awareness. For example, using paint with low or no volatile organic compounds was an issue that could be implemented quickly and integrated with future procurement practices. One longterm goal is to develop an education process that will increase the management staff's understanding of their decisions' implications.

The intergovernmental team encourages you to replicate the projects discussed in this report in your own governmental, commercial, or private buildings. Already, a number of corporations have undertaken greening efforts inspired by the Greening of the White House. In the public sector, the DOE's Federal Energy Management Program (FEMP), in association with other organizations, extends the greening process to other Federal sites. To help get the message out, FEMP and AIA developed an interactive CD-ROM explaining project lessons and technologies. FEMP also has a Greening of Federal Facilities Resource Guide for Federal energy managers that will help reduce energy consumption and costs, improve the working environment, and reduce the environmental impacts of their building. A Greening of the White House Web site went on-line in 1995, and Houston Lighting and Power Company produced a videotape documentary. Communicating the project's lessons and transferring this knowledge to the public is crucial to its long-term success. 


\section{Resources}

\section{General Energy Efficiency}

DOE Center of Excellence for

Sustainable Development www.sustainable.doe.gov/

DOE EREN Energy Saving Fact Sheets www.eren.doe.gov/erec/factsheets/factsheets.html

DOE Federal Energy Management Program http://www.eren.doe.gov/femp

DOE FEMP Greening Federal Facilities Web Site http://www.eren.doe.gov/femp/greenfed/

DOE BTS Energy Savers www.eren.doe.gov/consumerinfo/energy_savers/

EPA ENERGY STAR® Program www.epa.gov/energystar.html NPS Department of Energy Resources www.nps.gov/renew/doe.htm

Alliance to Save Energy - Energy

Efficiency Programs . www.ase.org/programs/index.htm

Alliance to Save Energy - Home and Business

Energy Checkup www.ase.org/checkup/index.html

Portland Energy Conservation, Inc. www.peci.org

\section{Building Design/Building Envelope}

DOE BTS Building Software Tools www.eren.doe.gov/buildings/tools_directory/

DOE FEMP Building Commissioning Guide www.eren.doe.gov/femp/techassist/bldgcomgd.html

DOE BTS Windows Guide www.eren.doe.gov/buildings/purchs_windows.html

DOE Center of Excellence for Sustainable

Development-Green Buildings www.sustainable.doe.gov/buildings/gbintro.htm

ORNL Building Envelope www.ornl.gov/roofs+walls/

NREL High-Performance Buildings Research www.nrel.gov/buildings/highperformance/

DOE/EPA ENERGY STAR $®$ Buildings www.epa.gov/buildings

DOE/EPA ENERGY STAR® Building Insulation www.epa.gov/appdstar/insulation/

DOE/EPA ENERGY STAR $®$ Roof Products www.epa.gov/appdstar/roofing/

Navy/GSA/DOE Whole Building Design Guide www.wbdg.org

NPS Guiding Principles of Sustainable Building Design www.nps.gov/dsc/dsgnenstr/gpsd/ch6.html

Advanced Technologies for

Commercial Buildings www.advancedbuildings.org/design.html

Sustainable Buildings Industry Council www.sbicouncil.org

Efficient Windows Collaborative www.efficientwindows.org

\section{Lighting}

DLA Lighting Site http://dscp103.dscp.dla.mil/gi/general/light1.htm

DOE FEMP Lighting Resources www.eren.doe.gov/femp/resources/lighting.html 
DOE BTS Lighting.

ENERGY STAR@ Residential Lighting

ENERGY STAR® CFL

Energy Efficient Lighting Association

Advanced Technologies for

Commercial Buildings

PECI Residential Services Lighting Program www.eren.doe.gov/buildings/purchs_lighting.html www.epa.gov/appdstar/fixtures/ .www.energystar.gov/products/cflbulbs.html www.eela.com/ www.advancedbuildings.org/lighting.html www.peci.org/res/lighting.html

\section{HVAC}

BTSHVAC

ORNL Heating and Cooling

NREL Desiccant Cooling Program

Advanced Technologies for

Commercial Buildings

DOE/EPA ENERGY STAR® Heating and

Cooling Equipment www.epa.gov/appdstar/hvac/index.html

\section{Plug Loads}

DOE FEMP Procurement, Buying Energy

Efficient Products http://www.eren.doe.gov/femp/procurement

DOE/EPA ENERGY STAR@ Home Appliances www.energystar.gov/products/appliances.html

DOE/EPA ENERGY STAR® Office Equipment .. www.epa.gov/appdstar/esoe/index.html Advanced

Advanced Technologies for Commercial Buildings www.advancedbuildings.org/load.html

\section{Environmentally Preferable Purchasing/Recycling}

Comprehensive Procurement Guideline for

Recycled Content Products www.epa.gov/cpg

Environmentally Preferable Products Purchasing .www.epa.gov/opptintr/epp

DOE Center of Excellence for Sustainable

Development - Materials Efficiency . .. www.sustainable.doe.gov/efficiency/materials/meintro.htm

National Recycling Coalition www.recycle.net

\section{Water}

DOE FEMP Water Conservation Program .. www.eren.doe.gov/femp/techassist/waterconserve.html

Cities and Counties Project. www.eren.doe.gov/cities_counties/articles.html\#water

DOE Center of Excellence for Sustainable

Development - Water Efficiency www.sustainable.doe.gov/efficiency/weinfo.htm

Clean Water Action Plan www.cleanwater.gov 
Vehicles

DOE Clean Cities Program

www.ccities.doe.gov

DOE Office of Transportation Technologies www.ott.doe.gov

DOE/EPAFuel Economy Site www.fueleconomy.gov/feg

ORNL Transportation Technologies www.ornl.gov/ORNL/Energy_Eff/transp.htm

American Council for an Energy-Efficient Economy - Green Guide to Cars and Trucks www.aceee.org/greenercars/index.htm

Rocky Mountain Institute Hyper Car Center www.hypercarcenter.org/dox/help01.html

\section{Landscaping}

DOE EERE Clearinghouse - Landscaping

for Energy Efficiency www.eren.doe.gov/erec/factsheets/landscape.pdf

DOE BTS Energy Savers - Landscaping www.eren.doe.gov/consumerinfo/energy_savers/ landscaping.html

\section{Indoor Air Quality}

FEMP Greening Federal Facilities Resource

Guide - Indoor Air Quality www.eren.doe.gov/femp/greenfed/7.0/index.htm

EPA's Indoor Air Quality Home Page www.epa.gov/iaq/

Envirosense (non-profit offering courses in indoor air quality improvement) www.envirosense.org

Advanced Technologies for

Commercial Buildings www.advancedbuildings.org/vent.html

EnviroCenter www.envirocenter.com/REnviroCenterHome.htm
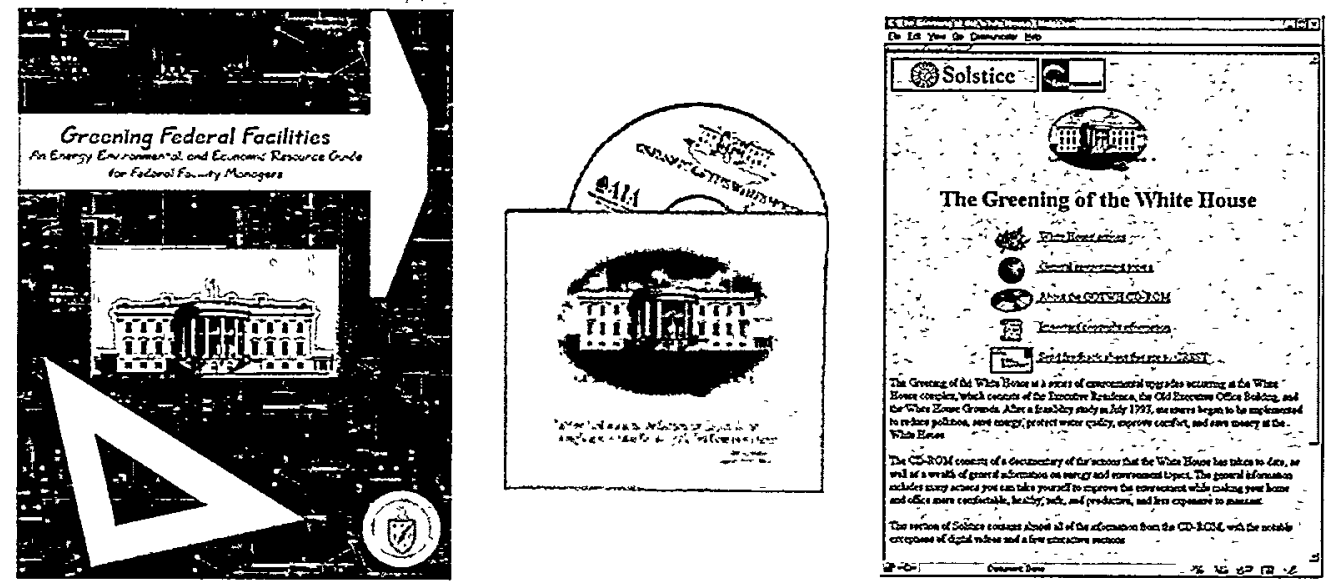

Greening of the White House Web Site www.crest.org/environment/gotwh/index.html 